\title{
Politics of faith: Transforming religious communities and spiritual subjectivities in post-apartheid South Africa
}

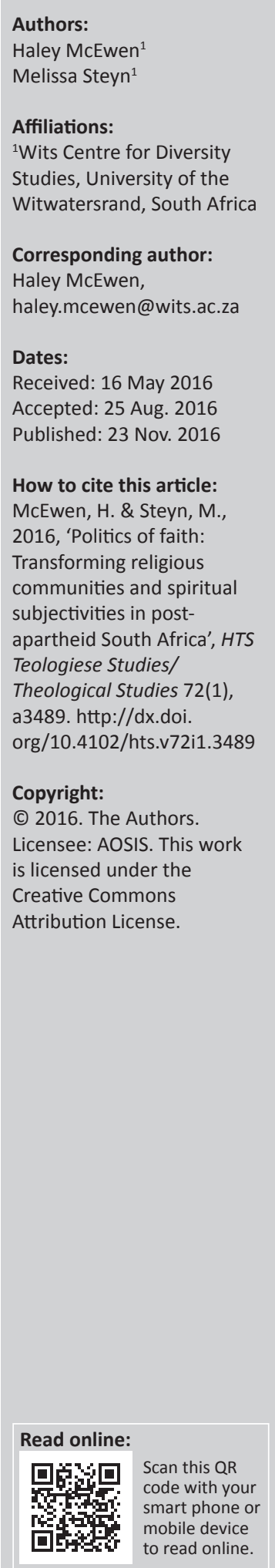

The enforcement of racial segregation during apartheid was aimed not only at regulating public spaces, residential areas and the workforce, but also at shaping the subjectivities of individuals who were socialised to see themselves through the lens of a white racial hierarchy. The ideology of white supremacy and superiority that informed apartheid policy was largely justified using Christonormative epistemologies that sought to legitimate the racial hierarchy as having basis in Holy Scripture and as an extension of God's will. At the same time, apartheid policy fragmented religious communities, entrenching race as a central component of spiritual subjectivities. Twenty years after the end of apartheid, the legacy of apartheid continues to shape the lives and opportunities of all people living in South Africa, despite many gains made in working towards a non-racial, non-sexist democracy. While much scholarly attention has been paid to postapartheid contexts of work, residency and recreation, relatively little attention has been paid to spaces of worship. This is surprising, given that religious belief and practice are widespread in South Africa in the first instance, and that Christian belief, in particular, was so central to the social imaginary of apartheid, in the second. Thus, in efforts to transform society and advance social justice, it is imperative to consider diversity, difference and otherness from the perspective of, and in relation to, contemporary religious communities and contexts. This article will consider some of the factors shaping dynamics of diversity and difference within the context of religious communities in South Africa, over 20 years into democracy.

\section{Introduction}

The issue of transformation in South Africa is profoundly one of diversity. As a result of the apartheid's oppressive regime of rigid racial segregation and hierarchy, the process of democratisation and redress has been largely characterised by state-led initiatives to dismantle structural and institutional racism installed by apartheid policies designed to protect white privilege and superiority. The apartheid regime employed space as a mechanism of maintaining racial difference, meaning that residential areas, educational institutions and places of worship and recreation were classified as being 'native', 'coloured', 'Asian' or 'white'-only spaces. Thus, as processes of social, economic and political transformation unfold in a new democratic era, new issues and debates pertaining to growing heterogeneity in these contexts continue to arise. Efforts to dismantle racism, sexism and other forms of oppression inscribed by colonialism and apartheid have been undertaken across sectors as well as in homes and other private spaces. This article considers diversity in the context of religious communities and contexts of worship, arguing that these sites are important elements of the broader project of instilling non-racialism and nonsexism into society, but have been largely overlooked within existing literature.

As scholarship in the social sciences has shown, every aspect of, and space for, civic, political and social engagement has a role to play in undoing the history of apartheid and colonial oppression. A large multidisciplinary pool of academic enquiry into transformation in South Africa has revealed that historical axes of oppression and racialised spatial segregation are being reinscribed and reconfigured in the new democratic era. Much attention has been paid to urban, suburban and rural residential areas, corporations, public recreational spaces and institutions such as schools, universities and civil services. Little attention, however, has been paid to transformation in religious communities and the faith sector broadly. Yet, multiple questions present themselves in relation to diversity in religious communities. On the one hand, there are questions to be considered around how religious communities and organisations account for or make sense of or

Note: This article is part of the Special Collection titled 'Negotiating Diversity in Christian Communities', sub-edited by Marilyn Naidoo of UNISA and Stephan de Beer of the Centre for Contextual Ministry, University of Pretoria. 
manage diversity in their own spaces. On the other hand, there are also questions to be asked around how religious communities interact in the broader society and the process of transformation. Furthermore, there is a dearth of locally grounded materials and models for transforming religious communities and organisations. While there have been some important contributions made by South African theologians in relation to these issues, there remains much work to be done in order to understand and engage with transformation in post-apartheid religious communities.

\section{Racialised spiritual subjectivities: Faith and politics in apartheid South Africa}

Racially segregated religious communities engaged with apartheid in a range of ways, from collusion and silence to resistance. The Dutch Reformed Church provided the spiritual sustenance for apartheid, while the leaders of many mainline churches (although not always with congregations on board) condemned apartheid, including the Methodist Church of Southern Africa, the Congregational Church, the Presbyterian Church, the Catholic Church and the Anglican church, with priest and anti-apartheid activist Trevor Huddleston (1956:245) declaring apartheid to be a heresy. The system, he argued, was 'fundamentally evil and basically un-Christian':

the desire to dominate in order to preserve a position of racial superiority and, in that process of domination, to destroy personal relationships, the foundation of love itself. That is antiChrist. (Huddleston 1956:245)

Furthermore, the extensive involvement of the Muslim community in the anti-apartheid struggle has been documented by Vahed (2012) and Esack (1988), and the significant contributions of the South African Jewish community have been documented by Adler (2000). In this sense, the history of apartheid and the struggle against it has irrevocably entangled faith and politics, regardless of the extent to which particular churches or denominations or belief systems chose to explicitly invoke politics or social realities in practice or to participate in the struggle against apartheid. There is a long and rich history of the involvement of South African religious communities and organisations in the struggle to end apartheid. Unfortunately, space does not allow us to elaborate extensively on this history here. However, racial segregation not only had consequences for spaces of worship, but also for worshippers, whose different realities had incalculable bearing on their spiritual subjectivities and identities. Therefore, in addition to apartheid entanglements of faith and politics were deepening intersections between race and faith that continue to shape spiritual subjectivities in South Africa today.

While significant achievements have been made in transforming South African society, the legacies of the past endure in many ways across the society. Research in nonreligious contexts has shown patterns of informal segregation across the society through which whites self-segregate residentially through processes of 'semigration' (Ballard 2004) and neighbourhood enclosure (Landman 2006) and also through their use of public recreational spaces (Byrne \& Wolch 2009), with the Durban beachfront providing a fruitful site for study in Dixon and Durrheim's (2003) study. Post-apartheid tourism destinations and industries have also been critiqued for reproducing historical racialised spatial segregation and inequality despite claims to generating wealth and employment (McEwen 2013). In workplaces (Booysen 2013) and universities (Alexander \& Tredoux 2010) researchers have shown how patterns of informal segregation and raced and gendered hierarchies are reproduced by Eurocentric and patriarchal organisational cultures. Other research has shown how young South Africans reproduce racial identities of the past (Dolby 2001; Walker 2005), and many have also shown how individuals who experienced apartheid continue to reinscribe racist ideologies through discourse (Steyn 2001) and narratives (Ansell 2004; Steyn \& Foster 2008). Research on the deepening of socio-economic inequality as a result of neoliberal policy makes important contributions to making sense of the global context in which these post-apartheid social dynamics unfold (Bond 2014; Carmody 2002).

In the light of the context of post-apartheid religious communities, this scholarship surfaces the question: How does the religious sector in South Africa, itself shaped by diversity, figure into the processes through which apartheid ways of doing, thinking and being are challenged or reproduced? This paper will look specifically at the relationship between whiteness and Christianity in the context of post-apartheid South Africa as a contested transformational space. While particular interpretations of the Bible were used to defend the white supremacist system of apartheid, critical theological confrontation with this history holds promise as a means through which the Dutch Reformed Church (DRC), in particular, can model and promote the role of religious communities as drivers of positive social change and transformation.

In this paper, we will consider religious communities in South Africa through the analytical lenses offered by the framework of Critical Diversity Literacy (CDL). Steyn (2015) defines CDL as:

an informed analytical orientation that enables a person to 'read' prevailing social relations as one would a text, recognising the ways in which possibilities are being opened up or closed down for those differently positioned within the unfolding dynamics of specific social context. (n.p.)

CDL employs an 'ethical sociopolitical stance in a world increasingly characterised by heterogenous spaces organisational, social and political', as well as an ontological orientation as 'an enabled mode of existence, congruent with the requirements of the emerging social imaginary of the 21st century' (p. 378). This 'reading practice' for diverse social contexts sets out 10 criteria for being critically diversity literate, with each holding power at the centre of analysis. Given the lack of empirical research on dimensions of diversity in the context of South African religious communities, 
this article draws on the analytic framework offered by CDL in order to offer an approach that can contribute to critical theological scholarship on diversity, difference and otherness in contexts of worship. This approach offers compelling insights into transformation in various social contexts because it approaches difference as being constituted and ordered by unequal relations of power, rather than carrying inherent or essential meaning. As Steyn writes, 'Far from reflecting a pre-given, natural order, all our categories for thinking about difference are socially constructed within unequal power relations' (p. 380). We invoke this approach in the context of religious communities in order to open up understandings of how spiritual and racialised subjectivities intersect in the context of postapartheid religious communities and organisation. Furthermore, we are interested in the intersection between racialised and spiritualised forms of power - namely, whiteness and Christianity, as key elements of the ways in which religious communities are shaped. The history of how the apartheid government utilised particular interpretations of Biblical texts in order to assert and enforce a white racist hierarchy requires that attention be paid to this intersection in the post-apartheid context in any discussion of diversity in religious contexts.

In employing CDL as an analytical framework, discussion also proceeds from an intersectional approach to identities and subjectivities in the racialised landscape of South African religious communities. According to Steyn (p. 381), 'systems of oppression intersect, interlock, co-construct and constitute each other'. Intersections between systems of dominance are central to their reproduction in instances where oppressed groups compete for advantage relative to one another and recreate hierarchies of oppression that prioritise their interests above those oppressed differently (p. 382). This structure of interlocking forms of power, dominance and oppression has been termed 'kyriarchy' by feminist theologian, Elizabeth Schussler Fiorenza (2013). According to Fiorenza, 'kyriarchy' is 'a complex pyramidal system of interlocking multiplicative social and religious structures of super-ordination and subordination, of ruling and oppression' (p. 49). Specifically, she argues that kyriarchal relations of power are built on the social dominance of white males and the exploitation of all women and colonised men. Yet, such relations of power are reproduced and multiplied in modern democracies, producing 'a different constellation of domination in different times and cultures' (p. 49). Fiorenza's analysis assists in understanding that systems of dominance and privilege are multifaceted, and that attempts to deconstruct and challenge hierarchies of power are most incisive when they acknowledge the ways in which these hierarchies are sustained by other oppressive orders.

According to Steyn, an aspect of acknowledging intersectionality is recognition of 'the processes that allow the relatively smooth reproduction of existing power relations such as those that invisibilise the norm, naturalise the status quo, construct ambiguities ... render some things unthinkable, [and] discourage envisaging other possibilities' (p. 388).
Attempts, therefore, to segment human lives and experiences into categories (such as race, class, gender, ability and disability) or genres and spheres (i.e. home life, personal life, political life, work life, religious or spiritual life, intimate or romantic life) risk the reproduction of hegemonic orders and the status quo. Our approach, therefore, rejects attempts to conceptually sever 'faith' and 'politics' into separate entities of the self or communities. As Magaziner (2007) writes, much scholarship has approached 'faith' and 'politics' dualistically, positioning Christianity as 'an instrument, a site of struggle, a tool to combat politics rather than politics itself' with politics being 'something that Christians do or do not do, ought or ought not to participate in' (p. 82). In apartheid South Africa, for instance, he writes that 'Conservative Afrikaner Christians worshipping in DRC churches were not merely seeking political gains through theological justifications - they believed them, held faith in them, acted on them' (p. 82). And, when a multiracial group of churchgoers declared apartheid a heresy in 1985, 'they were thinking politically about religion and religiously about politics' (p. 82). The history of apartheid in South Africa, therefore, provides an important illustration of 'faith' and 'politics' as existing in one sphere, rather than separate spheres as imagined by the 'divided mind of European postEnlightenment thought' (p. 82). This approach articulated by Magaziner suggests 'a new way of looking at religious engagement with politics (and its inverse) that emphasises the quality of that engagement, taking the thought and faith behind the actions seriously' (p. 82). We therefore argue that any attempt to understand diversity in the context of religious communities must resist the temptation to see 'faith' and 'politics' as distinct or separable. In the context of post-apartheid South Africa, this means that spirituality and race are inextricable.

\section{Unique characteristics of transformation in religious communities}

The unique challenges and opportunities within religious communities with regard to diversity and transformation remain largely unaccounted for and under-theorised. According to Rich (2001), for instance, the DRC 'has been a powerful defender of the status quo, [and] it can also be a powerful facilitator of change', in that white clergy continue to hold a direct line to power in South Africa, meaning that 'they can work from within the white power structure to bring about change' (p. 47). Rich also proposes that interracial religious groups can organise workshops and symposia, rallies and vigils, and that religious communities can find ways to work together to bring an end to the injustice that endures after the formal demise of the apartheid regime (p. 50). South Africa-based theologians have started to make important inroads to articulating issues of diversity, transformation and social justice using the conceptual resources already existing within Christian traditions. For instance, Jensen (2010) and Bentley (2013) have considered the Christian tradition of prophetic witness to discuss the 
possibilities for the DRC to foster and revive the alternative consciousness and voice offered by the Church. Van Wyngaard's (2014a) articulation of theological constructions for making sense of and engaging with diversity provide rich offerings to efforts to enable the Church to be an example of, and enabler of, change in the society. Naidoo's (2015) study provides rare and fruitful insights into diversity in Christian theological training institutions, showing the extent to which future Church leaders are being prepared adequately to attend to the complexities of diversity.

However, as mentioned above, the process of transformation in South Africa has not been easily undertaken, with historical legacies of inequality being reproduced despite Constitutional reforms aiming to create a non-sexist and non-racist society. Of course, while spaces such as beaches and corporations are markedly different with regard to how diversity and transformation take shape and there have been important ways in which these spaces have opened up since the demise of apartheid, scholarly research has generally found that ideologies of racial difference and patterns of informal segregation are being reproduced in new ways rather than deconstructed or eradicated. It remains to be uncovered how, if at all, religious communities are also undergoing such processes, and the extent to which advances have been made to transform within the faith sector.

As part and parcel of broader society, religious communities, like residential areas, public spaces, organisations and social institutions, have been inescapably shaped by the legacies of racial segregation and hierarchy inscribed by apartheid and colonialism. However, religious contexts are markedly different in view of the nature of their participation and membership. While one has relatively less agency regarding determining the extent to which one participates in the workplace (as a result of economic limitations and employer demands) or residential where one chooses to live (as a result of financial constraints, proximity requirements, the inconvenience of relocating, etc.), participation in a religious organisation is largely voluntary for members, who can increase or decrease their level of involvement at any stage. In this sense, religious contexts are more analytically comparable to recreational spaces in the post-apartheid landscape than they are to residential areas or places of work and study. Our hunch is that the freedom of movement amongst members of religious organisations creates a particular challenge to engaging with the challenging work of diversity and transformation. The personal work required in 'unlearning' many of the oppressive ways of knowing different differences is not easy and is profoundly characterised by feelings of discomfort, shame, uncertainty and fear. These are generally not affective dimensions of religious practice that appeal to those who worship regularly, and religious leaders working to keep their churches alive and well may fear the potential decline in membership and donations, in addition to other forms of resistance that often accompany diversity work should they attempt to mainstream deep transform. Thus, religious communities face unique barriers to transformation precisely because of what they offer members in view of security and certainty in the context of changing social relations.

At the same time, as Thornton writes, the shifting and opening up of enforced social boundaries in post-apartheid South Africa has created challenges for people, resulting in 'a "nostalgia" for the certainties, however grim, that [apartheid] offered'. Some religious communities, therefore, may be sought out by members precisely because they offer a space where members can remain in racially homogenous comfort zones. This possibility poses a particular challenge that members of religious communities may not welcome efforts to either become more racially diverse, or wish to spend time considering social injustice and inequality in the context of worship. As Vahed (2000) writes of the Muslim Indian community in Durban, South Africa - 'Muslims attempting to grapple with the questions posed by modernity and social diversity feel a sense of vulnerability and weakness in the face of these challenges and have found strength in Islam as a source of stability and identity' (p. 68). Vahed's study reveals one approach to understanding the relationship between religious communities and transformation, finding that deepening piety and religious identity can become a means of finding comfort in the context of uncertainty and change. Yet, while religious communities may provide comfort zones for its members, they may also simultaneously reproduce patterns of segregation and enable escape and evasion from personal and collective responsibilities in the face of gross inequality injustice in the broader society. Given Robinson's view that there is a turn to religion amongst those 'who are in a state of transition from one type of society to another', one is left wondering about how other religious identities are being reconfigured in the post-apartheid era (Robinson 1988) While his study is limited to the context of the Indian Muslim community in Durban, Vahed's findings open important questions for other religious communities in South Africa and the spiritual subjectivities shaping South African identities. The complexities of navigating the post-apartheid DRC are illustrated by van Wyngaard's (2014b) discussion of white Christian missiologist metaphors of 'border crossing', which can enable the construction of new identities, but most often reinscribe and protecting problematic white identities.

Transformation, in the context of CDL, is not merely an exercise of numbers, or of bringing in representative groups who have been historically marginalised and excluded. Rather, deep transformation work requires the deconstruction of the historical inequalities that are reproduced through everyday, unconscious and taken-for-granted actions. Theological scholars in the USA, for instance, have shown how white privilege and dominance are reproduced in churches, regardless of racial diversity amongst the congregation. While some theologians have hoped that racially integrated churches provided promise for the future of race relations in the USA, they have found that inequality and oppression are often reproduced in these spaces because of the continued centring of whiteness, which is reflected in the leadership, membership, representation and culture. As Edwards observed of interracial churches she studied in the USA: 
symbolic elements representing African-American, Latino or Asian culture during the worship services or in the physical space ... the more congregational characteristics, such as the theological orientation, worship service structure, sermonic presentation, and leadership structure, did not reflect the cultures of racial or ethnic minorities. (Edwards 2008:5)

Pointing to the affective dimensions of whiteness in spaces of Christian worship, Edwards writes, 'interracial churches with a substantial white attendance will work (by this I mean sustain a racially or ethnically diverse attendance) to the extent that they are first comfortable places for whites to attend' (p. 6). She argues that as a function of the ways in which whiteness operates to render white racialisation invisible, white church attendees showed 'limited interest in addressing race-related issues and accommodating the workshop and religious preferences' of other racial groups (p. 6). Thus, while for white congregants interracial churches may remain a comfort zone for their identities, these spaces could be experienced by black congregants as alienating and out of touch with the social realities of black existence in America today and historically.

\section{Crossroads of power: Christianity and whiteness in apartheid South Africa}

The DRC faces a unique challenge and opportunity in relation to diversity and transformation. Having provided the spiritual sustenance of apartheid, the DRC was implicated in apartheid policy, which the Nationalist Party (NP) declared to be 'in harmony with such Christian principles as justice and equity' (National Party 1947). Furthermore, the NP absurdly claims that it 'rejects any policy of oppression or exploitation of the non-whites by the Whites as incompatible with the Christian character of our people and therefore unacceptable'. It is clear that the NP was asserting a specific definition of Christianity in its manifesto; although a denomination is not named, the apartheid manifesto reports that the party was:

anxious to stimulate active christianising enterprise among the non-whites, [and] will gladly support the efforts of mission churches. Churches and missions, however, which frustrate the policy of apartheid or which propagate foreign doctrines, will not be tolerated. (National Party 1947 in Krüger 1960)

During the years of formal apartheid from 1948 to 1994, the DRC and the apartheid state were inextricably linked to the extent that some Afrikaners came to regard South Africa as being governed by a 'Christian theocracy', and the perception that the DRC was the 'NP at prayer' became a commonly used phrase (Rich 2001:42). At the time, the DRC had within its ranks 'most of the members of Parliament and provincial councils', and its members in control of many of the town councils with 'The vast majority of people employed by the government in various capacities and institutions, including the police and the military, belonging to the DRC' (de Gruchy in Rich 2001:41). Apartheid policy was justified and defended through the use of scripture in attempts to construct the segregation of racial groups as 'God's will'. Rich provides a discussion and critique of the biblical passages most often cited as supporting apartheid, referring to Genesis (11:1-9, 1:28), Deuteronomy (32:8-9) and Acts (2:11, 17:26). Despite the continued presence of some dissenting voices within the DRC that the Bible does not support the policy of racial segregation, "the "party line" of the white DRC has traditionally supported apartheid' and the apartheid era continues to be associated with the DRC post-apartheid in the popular imagination (p. 41). Given that the term 'apartheid' itself was coined by a DRC theologian, G. Cronje, it is unlikely that this association will ever be completely severed. However, as Rich argues, the DRC has enormous potential as a driver of social change and justice in the post-apartheid era and 'can strive to make their own churches a witness to what an integrated South Africa could be like' (p. 50).

Reflections on whiteness and Christianity more broadly, many of which emanate from the US context, offer some insight into how the oppressive history of the DRC can be transformed into a powerful intervention for equality and justice in society more broadly. Rich refers to the context of the USA, where Christians worked together to help bring about the end of slavery and segregation, to argue that 'Today, Christians working together can help end apartheid in South Africa' (p. 50). From the perspective advanced by Rich, the fact that 'not one of the verses cited as supporting apartheid actually does support it' reveals that 'The theological rationale for apartheid rests on misinterpretations, mistranslations, and ideological inferences.... In fact, the scriptural evidence is overwhelmingly against apartheid' ( $p$. 46). From this perspective, the DRC has the capacity to challenge the problematic interpretations of its predecessors and to become inclusive drivers of change in the present. This would involve, amongst the formation of discussion and action groups, the relentless attack on apartheid ideology in order to 'open the minds of their congregations' (p. 49).

Maluleke (1998) puts forth a productive provocation, pointing to Chipenda's (1995) juxtaposition of Africa's faces of Christianity and distress. Maluleke argues that Christian leaders and thinkers must use, rather than avoid, the tension between these faces as a cause for instrospection on the questions, 'Why is there such a massively distressed Africa in the midst of such a massively Christian Africa? Are these Africas accidentally or logically connected to one another? If so, how?' In the case of apartheid South Africa, he writes, Christianity was central to the problem of racial oppression, and that the role of Christianity in ending apartheid is therefore ambiguous (p. 333). 'Even more serious' he writes, 'is the question whether African Christians can guarantee that a Christian ontocracy such as Apartheid cannot reemerge in Africa' (p. 333).

In the light of the white supremacist ideology underpinning apartheid era interpretations of the Bible, the interrogation of apartheid ideology necessarily involves engagement with the ways in which whiteness and white supremacy have 
twisted Christian beliefs in the service of privilege and power. As critical whiteness scholars have argued, the deconstruction of whiteness is integral to the dismantling of systemic racism, and Christianity has long provided a key source through which many western notions of whiteness have been constructed. While colonial era constructions, classifications and rankings of 'racial' differences measured people according to physical features, the determination of who came to be classified as white and who did not was also determined by 'spiritual qualities', endowing 'true whiteness' with characteristics extending beyond that which is clearly visible or measurable in the body (Thompson 2014:51). Pointing to the anthropological work of Houston Stewart Chamberlain on the nature of the German people as the Aryan race, Thompson refers to his finding that 'Germans belonged to the Aryan race by virtue of their "spiritual qualities" rather than their biological ones' (p. 51). While Chamberlain utilised indicators such as skull measurement and blood analysis to delimit Aryans from non-Aryans, he found that not all Germans 'possessed the outward appearance proper to Aryans' and that this racial classification could be more accurately ascribed 'to the race-soul which they did share' (p. 51). Thus, while African, Asian and the Native peoples of the Americas became described exclusively by their bodily features and characteristics, those classified as white in Europe were the only group not seen to be 'contained nor fully determined by their bodies'. Whiteness became something beyond the corporeal, 'transcend[ing] and extend[ing] far beyond what is visible or tangible' (p. 51).

Whiteness itself, as a system of privilege and power, is maintained by being unseen and unnamed. As Dyer writes, 'whiteness resides in the non-corpreal.... Whiteness is the sign that makes white people visible as white, while simultaneously signifying the true character of white people, which is invisible' (Dyer 1999:51). Therefore, acts of naming and defining whiteness are a central component of efforts to dislodge white supremacy. In efforts to name white privilege in a contemporary Christian context, Magaziner extending Peggy McIntosh's (1990) seminal Knapsack of White Privilege, including: 'I can be quite sure of seeing Jesus depicted as a member of my race every Sunday', and 'I can see members of my race in virtually all the prominent positions of our national church body'. The interference that racism creates in one's relationship with the divine has also been discussed by Ratele (2005) who argued that as a result of extreme poverty and apartheid denial of the dignity and humanity, black people were subject to conditions that were unfavourable for the development of a 'soul'. And, as Philips elaborates:

If one knows one's desires and feelings, at least partly, from the outside in, how could those states have developed in circumstances where whatever reflection one received from the outside confirmed that one's existence barely registered and that one's desires and tender feelings did not matter? (Philips 2011:414)

Generating a cultural ethos in which both blacks and whites were socialised to believe that black people did not have souls 'was the essence of racial life' (p. 414).
In the US context, and arguably in the South African context as well, Christianity 'in all its varied and magnificent forms [as] yet to reckon with the incredible power of whiteness' (Thompson 2014:50). However, this encounter is necessary, as Thompson argues, in order to diagnose and cure the country of racism. He also argues:

Christians must take on the difficult work of understanding how whiteness has been woven like a cancer into their Christianity. It is the power of that whiteness to shape our social worlds defining good and bad, beautiful and ugly, true and false - that is at the heart the reason this wound will not heal. (p. 50)

Thus, the naming of whiteness is only the first stage of eradicating racism from Christianity and that the discourse must move beyond judgement and into a space where the 'gift of faith' can be used to break free from 'the white predisposition to revel in whiteness' (p. 54).

\section{Confronting racism in post- apartheid South African Christian communities}

Within South African society broadly, the reproduction of white privilege has been most recently named and confronted by student movements across the nation's institutions of higher learning. The campaign slogan \#RhodesMustFall and \#AfrikaansMustFall speak collectively to the grip that whiteness continues to retain within South African universities, with Cecil Rhodes and the Afrikaans language utilised as signifiers, not the be- and end-all, of white privilege and racialised inequities. For white Christians in South Africa, consideration of Gloria Albrecht's (2014:347) provocative argument that the question of racism is a question of faith' might open up fruitful spaces for reflection. In the US context from which she writes, Albrecht evinces that in the past, white conservative Christians blatantly endorsed lynching as part of its religion, while white liberal Christians remained largely silent about it. This history presents challenges to all white Christians today about their unconscious and unquestioned assumptions, norms, habits, stereotypes and behaviours of social institutions that reproduce whiteness and white privilege. Furthermore, this history requires Christians to question how they remain 'unable to see the vast injustices it inflicts upon other groups' in contemporary societies. She asks:

How could white Christian ethicists and theologians and pastors and church members fail to see black reality; or in seeing fail to understand this reality through the light of biblical justification faith; or in bringing this reality to biblical faith, how could some find biblical justification? (p. 347)

In the light of the history of terror incurred against black Americans by whites in the name of Christianity, Albrecht asks, 'How can it be possible that Black and White Christian Americans know the same God?' (p. 348).

Relaying this question to South Africa requires consideration of how apartheid policies enforcing racial segregation and 
hierarchies have shaped spiritual subjectivities. As Magaziner (2007) recalls, while for white Christians space could be viewed as 'abstract, open and available to be filled by human action in which the theologian might sense the divine', this 'was not the black majority's experience of space. For them, space was closed - where they lived, where they could travel, for how long they could stay once there' (p. 92). Consequently, while white members of the racially mixed United Christian Movement organised encounter groups as part of their annual conferences to address interpersonal relationships, 'many black students were eager to begin discussing the country's political situation in earnest' and 'liberating their oppressed people' (p. 93). The notion of 'sin' also opens up sites of understanding the racialisation of spiritual subjectivities. While white churches were preoccupied with the thoughts and actions of its congregants, black theologian Moloto argued that this approach 'distracted from the practical issues constraining black's lives' (p. 98). Black theology suggested that Jesus' fraternisation with supposed sinners meant that social sins outweighed individual ones, with the obvious implication that South Africa's greatest sin was 'the sin of oppression with which the black community has to live' (p. 98). In the light of the stark racial inequalities that continue to characterise South African society, Albrecht's question may be better phrased, Could it ever be possible that black and white worship the same God? and if so, is it possible for them to ever worship the same God together?

\section{Conclusion}

A critically diversity literate approach to religious community making and doing can open up new paths of knowing and being in post-apartheid South Africa and the 21st century globalising world. Naidoo's (2015) study of diversity in South African theological education provides an incisive illustration of how CDL can be applied to the context of religious organisations and communities. Naidoo concludes that theological training institutions must recognise their own situatedness and deconstruct the centrality and normativity of white, male, heterosexuality within their organisational cultures and curricula. Only then will these institutions become thriving spaces of debate, learning and reconciliation that will adequately prepare future religious leaders to play an effective role in South African society (p. 6).

The history of the DRC's collusion in apartheid makes it a particularly critical, rather than peripheral, site for transformation in post-apartheid South Africa. However, all religious communities have a role to play in social and economic transformation in South Africa. In this article, we have explored race as one dimension of diversity that must be confronted in religious communities, especially those which explicitly or implicitly colluded with the white supremacist apartheid regime such as the DRC. However, other facets of the self-kyriarchy served by apartheid such as heterosexism, heteropatriarchy and ableism must also be seriously confronted within religious communities in the post-apartheid era where these forms of discrimination continue to be perpetuated across the society. Moreover, critical theology of transformation in the South African religious sector has the opportunity to make important contributions to global discussions around diversity in religious organisations and communities. Diversity is increasingly becoming recognised as a reality of 21st century societies around the world, and religious communities are crucial stakeholder-members of these changing societies with a unique mandate and contribution to make in fostering the deep social change. The capacity of the religious sector to trouble the status quo through critical faith work and to offer meaning and vision of what an equitable and socially just society looks (and feels) like must be taken up as a central task of contemporary theologians and members and leaders within religious communities.

\section{Acknowledgements}

The authors would like to acknowledge the generous funding of the DST-NRF SARChI Chair Programme that has made the research possible.

\section{Competing interests}

The authors declare that they have no financial or personal relationships which may have inappropriately influenced them in writing this article.

\section{Authors' contributions}

The concept for this article was developed collaboratively by H.M and M.S. H.M. took the lead on writing the article.

\section{References}

Adler, F.H., 2000, 'South African Jews and apartheid', Patterns of Prejudice 34(4), 23-36. http://dx.doi.org/10.1080/003132200128810973

Albrecht, G., 2014, 'The heresy of white Christianity', CrossCurrents 64(3), 346-352. http://dx.doi.org/10.1111/cros.12091

Alexander, L. \& Tredoux, C., 2010, 'The spaces between us: A spatial analysis of informal segregation at a South African university', Journal of Social Issues 66(2) 367-386. http://dx.doi.org/10.1111/j.1540-4560.2010.01650.x

Ansell, A.E., 2004, 'Two nations of discourse: Mapping racial ideologies in postapartheid South Africa', Politikon 31(1), 3-26. http://dx.doi.org/10.1080/0258934 0410001690783

Ballard, R., 2004, 'Assimilation, emigration, semigration and integration: "White" people's strategies for finding a comfort zone in post-apartheid South Africa', in N. Distiller \& M. Steyn (eds.), Under construction: 'Race' and identity in South Africa today, pp. 51-66, Heinemann, Sandton.

Bentley, W., 2013, 'Defining Christianity's "prophetic witness" in the post-apartheid South African democracy', Studia Historiae Ecclesiasticae 39(1). http://www. scielo.org.za/scielo.php?pid=S1017-04992013000100003\&script $=$ sci arttext\&tlng=en

Bond, P., 2014, Elite transition: From apartheid to neoliberalism in South Africa, Pluto Press, London.

Booysen, L., 2013, 'Societal power shifts and changing social identities in South Africa: Workplace implications', South African Journal of Economic and Management Sciences 10(1), 1-20.

Byrne, J. \& Wolch, J., 2009, 'Nature, race, and parks: Past research and future directions for geographic research', Progress in Human Geography 33(6), 743-765. http://dx.doi.org/10.1177/0309132509103156

Carmody, P., 2002, 'Between globalisation and (post) apartheid: The political economy of restructuring in South Africa', Journal of Southern African Studies 28(2), 255-275. http://dx.doi.org/10.1080/03057070220140694

Chipenda, J., 1995, 'The church of the future in Africa', in D. Waruta (ed.), African Church in the 21st century: Challenges and promises, pp. 16-36, AACC, Nairobi.

Dixon, J. \& Durrheim, K., 2003, 'Contact and the ecology of racial division: Some varieties of informal segregation', British Journal of Social Psychology 42(1), 1-23. $\mathrm{http}: / / \mathrm{dx}$.doi.org/10.1348/014466603763276090

Dolby, N., 2001, Constructing race: Youth, identity, and popular culture in South Africa, SUNY Press, Albany, NY. 
Dyer, R., 1999, White: Essays on race and culture, Routledge, New York, NY.

Edwards, K.L., 2008, 'Bring race to the center: The importance of race in racially diverse religious organisations', Journal for the Scientific Study of Religion 47(1), 5-9. http://dx.doi.org/10.1111/j.1468-5906.2008.00387.x

Esack, F., 1988, 'Three Islamic strands in the South African struggle for justice', Third World Quarterly 10(2), 473-498. http://dx.doi.org/10.1080/01436598808420068

Fiorenza, E.S., 2013, 'Critical feminist studies in religion', Critical Research on Religion 1(1), 43-50. http://dx.doi.org/10.1177/2050303213476112

Huddleston, T., 1956, Naught for your comfort, Doubleday \& Company, Inc., New York, NY. Jensen, R., 2010, All my bones shake: Seeking a progressive path to the prophetic voice, Soft Skull Press, Boston, MA

Krüger, D.W., 1960, South African parties and policies 1910-1960, Bowes \& Bowes, London.

Landman, K., 2006, 'Privatising public space in post-apartheid South African cities through neighbourhood enclosures', GeoJournal, 66(1-2), 133-146. http://dx. doi.org/10.1007/s10708-006-9020-5

Magaziner, D., 2007, 'Christ in context: Developing a political faith in apartheid South Africa', Radical History Review 20(99), 80-106. http://dx.doi.org/10.1215/ 01636545-2007-004

Maluleke, T.S., 1998, 'Christianity in a distressed Africa: A time to own and own up', Missionalia 26(3), 324-340.

McEwen, H., 2013, 'Deserting transformation: Heritage, tourism, and hegemonic spatiality in Prince Albert', Diversities 15(2), pp. 23-36.

McIntosh, P., 1990, 'Unpacking the knapsack of white privilege', Independent School 49(2), 31-36.

Naidoo, M., 2015, 'Transformative remedies towards managing diversity in South African theological education', HTS Theological Studies 71(2), 1-7. http://dx.doi. org/10.4102/hts.v71i2.2667

National Party, 1947, 'Race relations policy of the National Party', viewed n.d., from http:// www.politicsweb.co.za/news-and-analysis/apartheid-the-nps-1947-manifesto

Philips, T., 2011, 'Race, place, and self in the experience of a bystander', International Journal of Psychoanalytic Self Psychology 6(3), 405-426. http://dx.doi.org/10.1080/ 15551024.2011.552408 Viewed 18 May 2016
Ratele, K., 2005, 'The interior life of Mtutu: Psychological fact or fiction?', South African Journal of Psychology 35(3), 555-573. http://dx.doi.org/10.1177/ 008124630503500310

Rich, G.P., 2001, 'Apartheid and Christianity', The Journal of Religious Thought 48(1), $38-50$.

Robinson, F., 1988, Varieties of South Asian Islam, Research Paper, Centre for Research in Ethnic Relations, University of Warwick, Coventry.

Steyn, M.E., 2001, Whiteness just isn't what it used to be: White identity in a changing South Africa, SUNY Press, Albany, NY.

Steyn, M.E., 2015, 'Clean air, clean water and diversity literacy: Essentials for the 21st century', in S. Vertovec (ed.), Routledge International handbook of diversity studies, pp. 239-389, Routledge, New York, NY.

Steyn, M. \& Foster, D., 2008, 'Repertoires for talking white: Resistant whiteness in post-apartheid South Africa', Ethnic and Racial Studies 31(1), 25-51. http://dx.doi. org/10.1080/01419870701538851

Thompson, D.A., 2014, 'Calling a thing what it is: A Lutheran approach to whiteness', Dialog 53(1), 49-57. http://dx.doi.org/10.1111/dial.12088

Vahed, G.H., 2000, 'Changing Islamic traditions and emerging identities in South Africa', Journal of Muslim Minority Affairs 20(1), 43-73. http://dx.doi.org/ $10.1080 / 13602000050008898$

Vahed, G.H., 2012, Muslim portraits: The anti-apartheid struggle, Madiba Publishers, Durban.

Van Wyngaard, C., 2014a, 'The language of "diversity" in reconstructing whiteness in the Dutch Reformed Church', in R.D. Smith, W. Ackah \& A.G. Reddie (eds.), Churches, blackness, and contested multiculturalism, pp. 157-170, Palgrave Macmillan, New York, NY.

Van Wyngaard, G.J., 2014b, 'White Christians crossing borders: Between perpetuation and transformation', in L. Michael \& S. Schulz (eds.), Unsettling whiteness, pp. 191-202, Interdisciplinary Press, Oxford.

Walker, M., 2005, 'Race is nowhere and race is everywhere: Narratives from black and white South African university students in post-apartheid South Africa', British Journal of Sociology of Education 26(1), 41-54. http://dx.doi.org/10.1080/01425 69042000292707 